Notre Dame Law School

NDLScholarship

2005

\title{
Bush v. Holmes: School Vouchers, Religious Freedom, and State Constitutions
}

Richard W. Garnett

Notre Dame Law School, rgarnett@nd.edu

Christopher S. Pearsall

Follow this and additional works at: https://scholarship.law.nd.edu/law_faculty_scholarship

Part of the Education Law Commons

\section{Recommended Citation}

Richard W. Garnett \& Christopher S. Pearsall, Bush v. Holmes: School Vouchers, Religious Freedom, and State Constitutions, 17 Educ. \& the L. 173 (2005).

Available at: https://scholarship.law.nd.edu/law_faculty_scholarship/843

This Article is brought to you for free and open access by the Publications at NDLScholarship. It has been accepted for inclusion in Journal Articles by an authorized administrator of NDLScholarship. For more information, please contactlawdr@nd.edu. 


\title{
Bush v. Holmes: School vouchers, religious freedom, and state constitutions
}

\author{
Richard W. Garnett ${ }^{\star}$ and Christopher S. Pearsall \\ Notre Dame Law School, USA
}

In Zelman v. Simmons-Harris, ${ }^{1}$ the Supreme Court of the US ruled that the First Amendment's Religion Clause, i.e. 'Congress shall make no law respecting an establishment of religion, or prohibiting the free exercise thereof', permits publicly funded school-voucher experiments that include private and religious schools. ${ }^{2}$ In other words, the Court made it clear-albeit by a narrow 5-4 margin-that governments do not unconstitutionally 'establish[]' religion merely by permitting eligible students to use publicly funded scholarships to attend qualifying religious schools, so long as the students' parents are able to make a 'true private choice' for the school their children attend. ${ }^{3}$

However, the Zelman decision left unanswered and unresolved many questions and problems. ${ }^{4}$ The general rule announced and applied can be stated in straightforward fashion: A publicly funded voucher program that indirectly aids religious institutions must be 'neutral with respect to religion' in that it provides assistance 'to a broad class of citizens defined without reference to religion' who then 'direct government aid to religious schools wholly as a result of their genuine and independent private choice. ${ }^{5}$ In practice, though, uncertainties remain.

For example, although the Justices determined that, all things considered, the particular program under review satisfied the First Amendment's requirements, they did not-and, indeed, could not-say anything definitive about the constitutional fate of other, differently structured, school-choice experiments. For example, the Ohio voucher program under review was enacted as only one part of a broader set of reforms and initiatives - some of which involved religious schools, while others did not-aimed at improving underperforming schools and assisting low-income students. Should the Religion Clause apply differently to a 'free standing' voucher program? The Ohio program targeted one particular, badly failing urban school district. ${ }^{6}$ Would the ruling in Zelman extend to a broader, state-wide (or even national) scholarship effort? And so on.

In addition to these, there are at least two more significant ways in which the Court's admittedly landmark decision in Zelman stopped well short of putting to rest

${ }^{\star}$ Corresponding author. 327 Law School, PO Box R, Notre Dame, IN 46556, USA. Email: Rick. Garnett.4@nd.edu

ISSN 0953-9964 (print)/ISSN 1469-5774 (online)/05/04173-11

(C) 2005 Taylor \& Francis

DOI: $10.1080 / 09539960500520297$ 
the vouchers question: For starters, although the Justices' ruling permits schoolchoice programs, it certainly does not require them; the debate over the policy merits and justice of such programs remains in the courts of public opinion, where powerful interest groups are sure to continue their opposition. ${ }^{7}$ In addition, the Zelman decision considered the validity of the Cleveland choice program under the Constitution of the US only; it did not address the fact that the States' own constitutions contain a variety of provisions that might constrain or prohibit choicebased reforms. Specifically, most States' constitutions include 'no aid' provisions that limit the flow of public funds, even indirectly, to religious institutions. ${ }^{8}$ Thus, even after Zelman, a school-choice program might well survive the vagaries of the legislative process, and overcome the self-interested objections of teachers unions and suburban parents, and satisfy in every way the First Amendment's requirements, but nevertheless break up on the rocks of a State's own, more rigorously separationist, no-aid provision.

Legislators in Florida followed - or, more accurately, they anticipated-Zelman's guidelines when, in 1999, they designed and enacted that state's Opportunity Scholarship Program. That is, they were careful to identify eligible schools and students without reference to religion and they offered a diverse array of benefits - including vouchers - to a broad group of students; offer benefits to a broad set of students; and offer those students a variety of publicly-financed options. The Opportunity Scholarship Program was designed to provide, among other things, tuition scholarships to students in failing schools. On the OSP model, the State Commissioner of Education is required by law to conduct an annual assessment of all schools in Florida and to assign a letter grade to each based on two principal factors, first, the school's overall performance on a statewide standardized test and, second, the improvement of the lowest $25^{\text {th }}$ percentile of students in reading, math, or writing on the same statewide standardized test. ${ }^{9}$ If a school receives a grade of ' $F$ ' on the state assessment for two school years in any four-year period, its district must notify all parents with children in the failing school of the state's classification and inform them of their eligibility to choose other options. ${ }^{10}$ Under the law, a parent could choose to enroll their child in a higher performing public school within the district, transportation costs included. ${ }^{11}$ Or, a parent could also choose a higher performing public school in an adjacent school district and transport the child to their new school. ${ }^{12}$ More controversially, a parent may request an Opportunity Scholarship for tuition at a participating private school. ${ }^{13}$ If a parent elects this option, she receives from the state a voucher, redeemable at any eligible, participating private school. ${ }^{14}$

Although the Florida program differs in several respects from the Ohio experiment that was considered in Zelman, it is fairly clear that the Opportunity Scholarship Program does not run afoul of the First Amendment to the US Constitution. Accordingly, after their defeat in the legislature, the usual cadre of school-choice opponents elected to attack the program in the courts of Florida, using that State's constitution. $^{15}$ 
These opponents' challenge was recently decided by the Florida Supreme Court. Indeed, the case-captioned Bush v. Holmes - traveled up and down the State's judicial system for over six years. In the trial court, the judge initially found-without hearing any evidence - that the Opportunity Scholarship Program violated Article IX, $\ 1$ of the Florida Constitution. That Section provides, among other things, that '[a]dequate provision shall be made by law for a uniform, efficient, safe, secure, and high quality system of free public schools that allows students to obtain a high quality education and for the establishment, maintenance, and operation of institutions of higher learning and other public education programs that the needs of the people may require.' The trial court decided that the legislature intended that Article IX, $\int 1$ establish - by negative implication - a mandate that the government may only provide a high quality education by funding public schools. ${ }^{16}$ On appeal, ${ }^{17}$ Governor Jeb Bush and the other defendants argued that the trial court had erred in not hearing any evidence and also that the Opportunity Scholarship Program does not, in fact, violate the Florida Constitution. The Florida District Court of Appeal reversed. Rejecting the trial court's finding that Article IX, $\ 1$ prescribes the sole means for educating the children of Florida, the Court of Appeal held: '[A]rticle IX, $\ 1$ does not unalterably hitch the requirement to make adequate provision for education to a single, specified engine, that being the public school system. ${ }^{18}$

On remand, the trial court ruled again for Ruth Holmes and the other plaintiffs, but this time on different grounds, namely, that the program violated Article I, $₫ 3$ of the Florida Constitution. That section - captioned 'Religious freedom' - substansubstantially tracks the First Amendment's Religion Clause, but also declares that ' $[\mathrm{n}]$ o revenue of the state or any political subdivision or agency thereof shall ever be taken from the public treasury directly or indirectly in aid of any church, sect, or religious denomination or in aid of any sectarian institution. In the trial court's judgment, the Florida program violated this provision because, whatever the good intentions of the program, the OSP provides tuition money to children that ultimately flows to religious schools aid 'aids' them in their mission. The defendants appealed, but were unsuccessful. The Appeals Court upheld the trial court's decision, first as a panel and then again en banc. ${ }^{19}$ An eight-judge majority found that the Opportunity Scholarship Program violated Article I, $\ 3$, reading the third sentence quoted above to prohibit any indirect benefits to religious schools that might accrue when children direct their tuition vouchers to those schools. Five of those eight judges would also found that the program violates Article IX, $\int 1 .^{20}$ Five other judges dissented, insisting that, properly understood, Article I permits the legislature to employ religion-neutral vouchers as a means of improving education in the state. ${ }^{21}$ The dissent concludes, '[b] ecause the Florida no-aid provision is no more restrictive than the US provision, the Florida program should be ruled constitutional as was the program in Zelman.'22

The Florida Supreme Court agreed to review the case, and heard oral arguments on 7 June 2005. Ultimately the Article IX, $\int 1$ issue controlled when the Court decided the case on January 23, 2006. Writing for a 5-2 majority, Florida Chief Justice Pariente concluded that, ' $[\mathrm{t}]$ he OSP contravenes [Article IX, $\mathbb{\complement}$ ] because it 
allows some children to receive a publicly funded education through an alternative system of private schools that are not subject to the uniformity requirements of the public school system. ${ }^{, 23}$ These 'uniformity requirements' refer to standardized state curricula, teacher certification requirements, and direct oversight by the state. Although most private and parochial schools in Florida have and follow their own objective accreditation, curriculum, and teacher certification standards, ${ }^{24}$ the fact that these standards differ from Florida's uniform state standards ultimately doomed the OSP in the eyes of the Florida Supreme Court. ${ }^{25}$ The dissent, authored by Justice Bell, sharply criticized the majority's methods of statutory construction and lack of deference to the legislature's authority. Regardless, the Florida Supreme Court addressed only a 'narrow question" ${ }^{26}$ when it ultimately disposed of Bush v. Holmes, and consequently the interpretation of much of the relevant provisions in Florida's Constitution still remains contested.

At the heart of this case - and, in all likelihood, at the heart of the Florida Supreme Court's decision - are two provisions of the Florida Constitution: Article IX, $₫ 1$ and Article I, \3. Article IX, again, reflects the importance of education to its drafters and to the State. It declares that ' $[\mathrm{t}]$ he education of children is a fundamental value of the people of the State of Florida,' and then makes it a 'paramount duty of the state to make adequate provision for the education of all children residing within its borders.' The interpretive controversy in Bush v. Holmes centers on the above-quoted text that follows: 'Adequate provision shall be made by law for a uniform, efficient, safe, secure, and high quality system of free public schools that allows students to obtain a high quality education and for the establishment, maintenance, and operation of institutions of higher learning and other public education programs that the needs of the people may require.'

According to the plaintiffs in Holmes, this language is not only aspirational, and it does more than prescribe the ends or goals of education-related legislation. That is, they understand Article IX not only as a mandate for a 'system of free public schools,' but also as implicitly prohibiting education-related disbursals to private schools, or students attending them. In their view, the Article specifies the only constitutionally permissible way the state may make 'adequate provision' for education. The first part of Article IX, $\int 1$ expresses the general duty of the state to 'make adequate provision' for every child's education; the second part prescribes specifically how adequate provision 'shall be made.' In other words, expressio unius est exclusio alterius: by specifying one thing the state must do to fulfill its mandate (i.e. establish free public schools), the Constitution says also that it may not do anything else (i.e. enact and fund the Opportunity Scholarship Program). ${ }^{27}$

The government's interpretation, on the other hand, is decidedly less restrictive - and more straightforward. It concedes that Article IX, $\ 1$ imposes a duty on the state to provide for public education, but maintains that legislature retains wide discretion when fulfilling its mandate, as it does with most matters. ${ }^{28}$ Rather than making less than 'adequate provision' for education, the Legislature by enacting and funding the OSP is going beyond what the Constitution requires for the children of Florida. After all, the state already has a system of free public schools. 
The Opportunity Scholarship Program was enacted as an innovative attempt to improve under-performing public schools by increasing competition and raising expectations. At the same time, the OSP provides individual students trapped in failing schools an opportunity for a better education. The Legislature's reasons for enacting the program are well in accord with the overarching theme of Article IX, $₫ 1$, which is to provide for the education of all children in the state. Doing more than what is simply 'adequate,' by enacting additional programs beyond what is constitutionally required, cannot be less than 'adequate' and therefore cannot violate Article IX, $₫ 1$.

The plaintiffs, for their part, countered by acknowledging that the Legislature has plenary power to create programs not provided for in the state Constitution, but insisting that this power does not extend to actions taken in lieu of actions specifically mandated by the Constitution. It is hard to see, however, how the creation of the OSP is an action taken 'in lieu of' establishing and maintaining a public school system. Still, the plaintiffs' view is that an interpretation of Article IX, $\mathbb{1} 1$ permitting the OSP would mean that, under the state Constitution, Florida must do no more than provide children with the option of attending a public school, and that the state could theoretically transfer its education funding to private schools through a future program. But even putting aside the fact that the OSP's benefits are limited to students in failing public schools, and that the program is designed to improve the public school system, public schools in the US have long been an option provided by the states for parents to choose, or not. ${ }^{29}$ Parents already retain the liberty to choose their children's schools by electing to send their children to private or parochial school, or even by choosing to move within the boundaries of a favored public school district. Of course, exercising any of those options requires the financial power to do so. In some ways, then, the OSP can be construed as an extension of that power to less economically privileged families stuck in failing public school districts.

As was noted earlier, the Florida Supreme Court initially declined, during the first appeal, to consider the Article IX, $₫ 1$ issue. Still, resolving the case on Article IX, $₫ 1$ grounds may have been attractive to some Justices because doing so insulates the case from review and possible reversal by the Supreme Court of the US. This is because the Florida Supreme Court has the final word on the meaning of its own Constitution. Thus, a ruling by that Court that, under Article IX, the Legislature may not provide private-school vouchers to children in failing schools would not set up any federal questions for the Supreme Court of the US to resolve.

In any event, the heart of matter in the lower courts on this appeal, and of the question certified for review by the Florida Supreme Court, was not the state constitution's public-education provision, but instead its religious-freedom text, Article I, $\mathbb{\Omega}$. That section, as has already been noted, reads: 'There shall be no law respecting the establishment of religion or prohibiting or penalizing the free exercise thereof. Religious freedom shall not justify practices inconsistent with public morals, peace or safety. No revenue of the state or any political subdivision or agency thereof shall ever be taken from the public treasury directly or indirectly in aid of any church, sect, or 
religious denomination or in aid of any sectarian institution' (emphasis added). The first sentence of this section is, of course, a near-restatement of the First Amendment's Religion Clause. And, again, it is not seriously contended that the OSP contravenes the First Amendment, as understood by the contemporary Supreme Court. ${ }^{30}$ The question raised by Bush $v$. Holmes in the lower courts, then, is whether the rest of the language in Article I, $\int 3$ forbids the state from enacting a program like the OSP. Certainly the second sentence imposes no such limit; it was inserted in 1885 as part of the Reconstruction of the south following the Civil War to limit the exercise of religion. ${ }^{31}$ It is the third sentence - the 'no aid' provision-that was the basis for the Florida District Court of Appeal's ruling that the OSP is unconstitutional.

The Florida District Court of Appeal endorsed the plaintiffs' interpretation of Article I, \3, which would allow the state far less leeway than does the First Amendment in creating programs and partnerships with religious institutions to provide general public benefits. On this reading, the third sentence of Article I, $\int 3$ was deliberately included in the ratified Constitution of 1968 and therefore, 'necessarily imposes restrictions beyond the Establishment Clause. ${ }^{32}$ These restrictions are so tight, according to the Appeals Court, that any indirect or secondary benefit to sectarian institutions from the use of state funds would be sufficient to violate the provision,' regardless of the degree to which other non-sectarian institutions or the general public directly benefits. ${ }^{33}$ In other words, despite the fact that the direct beneficiaries of the OSP are the children and their parents who may endorse a government-sponsored voucher to whatever participating private school they choose, the OSP is unconstitutional under Article I, $\ 3$ because endorsing a voucher to a religious school confers an indirect benefit to the school. ${ }^{34}$

The trouble with the Appeals Court's interpretation, the government counters, is that a number of past Florida Supreme Court cases suggest that Article I, $₫ 3$ should not be interpreted so narrowly. Tax exemptions for homes for the aged owned by religious organizations, ${ }^{35}$ revenue bonds issued by the state for the aid of both religious and non-religious schools, ${ }^{36}$ perpetual easements in a large land grant to the government for a church to use a local lake for baptisms, ${ }^{37}$ and making public school buildings available to churches on Sundays for religious services ${ }^{38}$ have all been held constitutional by the Florida Supreme Court because of the secular purpose that the programs further and the general applicability of the program. In light of these cases, the phrase, 'in aid of,' should not be understood to mean 'results in any benefit to, no matter how small,' but rather, 'for the purpose of aiding.' For example, a tax exemption offered to all homes for the aged, both religious and non-religious, is enacted in aid of the elderly population of Florida. Even though offering a tax break to both religious and non-religious homes for the aged may result in the religious homes receiving some incidental benefit, these indirect contributions are not in aid of' the religious institution or its mission. The government is not trying to aid religion, but rather the aged population within the state. Put differently, 'when public financial benefits enjoyed by religious institutions are merely incidental to the achievement of a non-sectarian public purpose, there is no violation of article I, 
section 3.,39 It was on this understanding that the Florida Legislature enacted the OSP for the purpose of aiding under-privileged students and spurring certain public school districts to improvement. ${ }^{40}$

In addition to case law, the parties in Bush v. Holmes looked to the history and context of Article I, $₫ 3$. In 1875, Speaker of the House James G. Blaine proposed an amendment to the US Constitution that would have prohibited any state tax revenues for education from aiding 'any religious sect. ${ }^{41}$ Blaine's proposal failed in the Senate by four votes, supporters of the amendment were able to convince some states to enact similar provisions in their state constitutions, and also were able to make adoption of similar provisions a requirement for new states entering the Union after $1875 .{ }^{42}$ These amendments generally became known as 'Blaine Amendments.'

Now, at that time, the public, or 'common,' schools were regarded by their supporters - and, more particularly, by Protestant Christians - as 'non-sectarian' institutions. In the mid- and late- $19^{\text {th }}$ century, 'non-sectarian' in the education context did not mean 'secular,' but generally Protestant. As Catholic immigrants began resisting a curriculum meant to indoctrinate students with Protestant values, however, anti-Catholic forces emerged to counter them. Chief among the antiCatholic forces' aims was to preserve tax revenues for common schools exclusively, hence legislative enactments in the spirit of James G. Blaine, like Florida's Article I, $\mathbb{S}$ 3 , enacted for the first time in the Florida Constitution of $1885 .{ }^{43}$

This history is relevant to the dispute in Bush $v$. Holmes because it strengthens the claim that the third sentence of Article I, $₫ 3$ was meant to bar programs like the OSP. Even if rooted in anti-Catholicism, the plaintiffs argue in so many words, the intent was clearly to prevent tax revenues from being used to fund sectarian education in Catholic schools. And, the government admitted at oral argument, the nasty history coloring Article I, $\mathbb{} 3$ is not sufficient grounds either to save the OSP, or invalidate section $3 .^{44}$

That said, if the Florida Supreme Court had invalidated the OSP on Article I, $\$ 3$ grounds, they probably would have created an issue that could be reviewed by the Supreme Court of the US. As the government has contended throughout the Holmes litigation, Blaine amendments may conflict with rights guaranteed under the US Constitution, specifically the Free Exercise Clause contained in the First Amendment. ${ }^{45}$ And, of course, the Supreme Court of the US has the power to strike Article I, $₫ 3$ from the Florida State Constitution entirely if it conflicts with he First Amendment of the US Constitution. In fact, the Supreme Court of the US recently considered an argument that a generally applicable scholarship program in Washington state violates the Free Exercise clause of the First Amendment because it prohibits recipients from pursuing a theology degree in Locke v. Davey. ${ }^{46}$ The Washington program was found not to violate the Free Exercise clause. While this case would certainly have been cited in a further appeal of Bush v. Holmes, the Supreme Court's narrow holding in Locke is far from dispositive. Thus, those backing a reformed OSP and similar programs in the future could possibly lose the battle in Florida but win the war in Washington, DC if a case like Bush v. Holmes is eventually decided on Article I, $₫ 3$ grounds. 
Though the constitutionality of school choice programs is, as a general matter anyway, settled under the federal Constitution, the constitutionality of individual programs at the state level is still at issue around the country. Bush v. Holmes is the latest legal fight in the broader movement within America to increase educational opportunity for the underprivileged through school voucher programs. In enacting the OSP in 1999, Florida was the first state to institute a school choice program statewide, and others have followed suit. ${ }^{47}$ It also ended up being the first statewide school choice program invalidated by its state Supreme Court. Nevertheless school choice supporters and opponents alike are sure to draw lessons from the litigation in Bush v. Holmes when making their next moves.

\section{Notes}

1. 536 US 639 (2002).

2. Zelman involved a challenge to the state of Ohio's 'Pilot Project Scholarship Program.' Ohio Rev. Code Ann. SS 3313.974-3313.979 (West 2005). This program provides, and funds, a number of education-related benefits and options to low-income parents of Cleveland schoolchildren including, but not limited to, vouchers redeemable at private, religious schools that participate in the program.

3. See Zelman, 536 US at 650.

4. For detailed and helpful discussions of Zelman, its implications, and the issues left unresolved, see, e.g., Thomas C. Berg (2003) Vouchers and Religious Schools: The New Constitutional Questions, U. Cinn. L. Rev., 72, 151; Ira C. Lupu \& Robert W. Tuttle (2003) Zelman's Future: Vouchers, Sectarian Providers, and the Next Round of Constitutional Battles, Notre Dame L. Rev. , 78, 917.

5. Zelman, 536 US at 928-29. Professors Lupu \& Tuttle explain the governing doctrine in this way: "As a threshold requirement, the aid program must be "neutral in all respects toward religion." By this, the Court simply means formal neutrality-the classes of both the participating schools and the eligible students must be defined in non-religious terms... Next, the program must provide aid "directly to a broad class of individuals, defined without reference to religion." Lastly, "The aid recipients must be "empowered to direct the aid to schools or institutions of their own choosing." Lupu \& Tuttle, Zelman's Future, supra note 6 at 928 (quoting Zelman, 536 US at 653-54).

6. Under the Ohio program, if a local school district fell into such dire straits so as to require state intervention, the law forced the local superintendent of that district to create an assistance program for families within district boundaries. Ohio Rev. Code Ann. \$3313.975 (West 2005). At the time of the program's enactment, Cleveland's schools were acknowledged as some of the worst in the nation. See generally Reed v. Rhodes, 1 F. Supp. 2 d 705 (N.D. Ohio, 1995).

7. For an argument that choice-based education reform that respects parents' choices for religious schools is both sound and just, see Richard W. Garnett (2002) The Right Questions About School Choice: Education, Religious Freedom, and the Common Good, Cardozo L. Rev. 23, 1281.

8. These no-aid provisions are often referred to generally as 'Blaine Amendments,' after the Congressman - and failed presidential candidate from Maine - who spearheaded an effort in the late 19th Century to add to the US Constitution an amendment providing, among other things, that 'no money raised by taxation in any State for the support of public schools, or derived from any public fund therefor, nor any public lands devoted thereto, shall ever be under the control of any religious sect; nor shall any money so raised or lands so devoted be 
divided between religious sects or denominations.' Although this effort failed, similar provisions were inserted over time in the constitutions of nearly forty States. The primary purpose of, and motive underlying, both the Blaine Amendment and the similar state-level provisions was to curtail the perceived power and negative influence of the Roman Catholic Church and its schools. See generally, e.g., Richard W. Garnett (2003) The Theology of the Blaine Amendments, First Amend. L. Rev. 2, 45.

9. Fla. Stat. Ann. ch. 1008.34 (2005). Similar to the standard American grading system for students, the Florida grading system for schools translates as follows: ' $\mathrm{A}$ ' $=$ schools making excellent progress; ' $\mathrm{B}$ ' $=$ schools making above average progress; ' $\mathrm{C}$ ' $=$ schools making satisfactory progress; ' $\mathrm{D}$ ' $=$ schools making less than satisfactory progress; ' $F$ ' $=$ schools failing to make adequate progress.

10. Fla. Stat. Ann. ch. 1002.38(3)(a)(1) (2005).

11. Fla. Stat. Ann. ch. 1002.38(3)(a)(2) (2005).

12. Id.

13. Fla. Stat. Ann. ch. 1002.38(2) (2005).

14. Fla. Stat. Ann. ch. 1002.38(6)(g) (2005).

15. See, generally, Richard Fossey and Robert LeBlanc (2005) Vouchers for Sectarian Schools after Zelman: Will the First Circuit Expose Anti-Catholic Bigotry in the Massachusetts Constitution? West Educ. L. Rep. 193, 343, 348-350 (presenting a survey of the groups who opposed school vouchers in the Zelman case and their pledge to continue fighting vouchers in state courts). See also Lupu \& Tuttle, supra, at $956 \mathrm{nn} .175-81$.

16. Bush v. Holmes, 767 So. 2d 668, 673 (Fla. Dist. Ct. App. 2000).

17. A description of Florida's court system is available online at: www.flcourts.org/. Florida, like many American jurisdictions and the federal system has a three-tiered court system consisting of trial courts (called Circuit and County courts in Florida), intermediate appellate courts (called District Courts of Appeal in Florida), and a Supreme Court. The Supreme Court in Florida does not hear appeals in every case but, like the Supreme Court of the US, may grant a petition for certiorari if the case meets the requisite level of importance.

18. Bush v. Holmes, 767 So. 2 d, at 675 . The Florida Supreme Court declined to review the case at this point. Holmes v. Bush, 709 So. 2d 1104 (Fla. 2001) (cert denied).

19. Bush v. Holmes, 886 So. 2d 340 (Fla. Dist. Ct. App. 2004). In cases of sufficient importance, an en banc review may be granted. Such hearings consist of the full Court of Appeals sitting together, rather than the usual smaller panel of judges. Opinions rendered en banc replace the initial panel opinion of the Court of Appeals.

20. Id. at $367-71$.

21. Id. at 371-93.

22. Id. at 387 (Polston, J. dissenting).

23. Bush v. Holmes, No. SC04-2323, slip op. at 34 (Fla. Jan. 23, 2006).

24. For example, the Florida Catholic Conference maintains an independent accrediting body for its schools. See http://www.flacathconf.org/Accreditation/aboutus.htm.

25. Chief Justice Pariente noted the 'numerous nonpublic accrediting bodies that have "widely variant quality standards and program requirements"' as well as 'curriculum standards of eligible private schools [that] may vary greatly depending on the accrediting body, and [that] these standards may not be equivalent to those required for Florida public schools.' Bush $v$. Holmes, slip op. at 30. She did not, however, acknowledge the possibility that some nonpublic accrediting and curriculum standards may be more demanding and scrutinizing than the public school system's. It is far from clear what educational value is served by 'uniformity' when a school's eligibility to receive opportunity scholarship students depends on its willingness to submit to state standards that are arguably inferior in some cases.

26. Bush v. Holmes, slip op. at 2.

27. In addition, Article IX, $₫ 6$ of the Florida Constitution may end up influencing the Florida Supreme Court's interpretation of Article IX, $\mathbb{\complement}$ 1. Indeed, several Justices focused their 
questions during oral argument on the relationship between the two sections. Article IX, $₫ 6$ states that money from the School Trust Fund, a fund established in 1868 as a way to manage income generated from a federal land grant meant to support Florida's schools, may only be appropriated to support the free public schools. The plaintiffs argue that since the State School Fund was the sole financial support for education in the 1868 Constitution, and since it was limited to funding the public schools, Article IX, $₫ 6$ reflects an historical commitment that the state may only fund free public schools. While this theory is no longer asserted as an independent ground for the OSP's unconstitutionality, the plaintiffs contend that Article IX, $₫ 1$ must be read in light of Article IX, $₫ 6$. If the only way to make 'adequate provision' as mandated by Article IX, $₫ 1$ was through a fund limited to public schools, Article IX, $\ 6$ too specifies how the state can fulfill its mandate - only through the public schools. However, asserting Article IX, $₫ 6$ as an independent ground for the OSP's unconstitutionality raises several difficulties. For starters, the OSP is not funded by the School Trust Fund, but rather through the state's general revenues. What's more, the landscape of educational funding in Florida is more complex than it was in 1868.

28. Bush Br. at 43 [full citation to brief] (stating that the Legislature is vested with 'enormous discretion' when carrying out its mandate) Also, the government argues that the OSP is another program that the 'needs of the people may require' as provided for in Article IX, $\mathbb{} 1$. All documents in this case are available online at: www.floridasupremecourt.org/pub_info/ voucher/index.shtml.

29. Pierce v. Society of Sisters, 268 US 510 (1925) (establishing the right of parents to choose their child's school by rendering an Oregon law mandating attendance at public schools only unconstitutional).

30. It is likely, though, that an earlier Supreme Court would have invalidated the Program. In Committee Pub. Ed. V. Nyquist, the Supreme Court struck down a New York program that provided tuition reimbursements to families with children in religious schools on the grounds that the reimbursements had the effect of advancing religion in violation of the Establishment Clause. 413 US 756 (1973). The analysis under Zelman is more favorable to such programs as discussed above.

31. Bush v. Holmes, 886 So.2d 340 (Fla. Dist. Ct. App. 2004) (citing Talbot 'Sandy' D’Alemberte, Commentary, art. I, \3, 25A Fla. Stat. Annot. 79 (1991)).

32. Id. at 351 .

33. Id. at 352 .

34. This interpretation is consistent with the interpretation that some state courts have put on their 'Blaine Amendments.' Others, though, have read their similarly worded no-aid provisions as imposing no greater restrictions than the Establishment Clause.

35. Fohnson v. Presbyterian Homes, 239 So. 2d 256 (Fla. 1970).

36. Nohrr v. Brevard County Educ. Facilities Auth., 247 So. 2d 304 (Fla. 1971).

37. Koerner v. Borck, 100 So. 2d 398 (Fla. 1958).

38. Southside Estates Baptist Church v. Board of Trustees, 115 So. 2 d 697 (Fla. 1959).

39. Bush Br. at 17.

40. As the government emphasizes, the OSP is not the only program that the government feels is threatened by the Court of Appeal's reasoning. Appendix F to the Governor's initial brief includes a list of 37 programs designed to improve the public welfare in education, health, corrections, and other areas that result in some incidental benefit to religious organizations. There are already 19 such programs designed to improve education in Florida. Should Article I, $\llbracket 3$ be read so narrowly as to invalidate any program that results in even a small benefit to religion, these programs are at risk. The government asserts such a ruling therefore leads to 'absurd results' where 'no religious organization could ever rent... or occupy any public property.' Bush Br. at 15 (citing Southside Estates, 115 So. $2 \mathrm{~d}$ at 700 ) (the court in Southside Estates rejected an argument that, 'regardless of how small ... if anything of value 
can be traced from the public agency to the religious group, the Constitution has been thereby violated.' Id. at 699).

41. The relevant text of Rep. Blaine's amendment read: ' $[N]$ o money raised by taxation in any State for the support of public schools, or derived from any public fund therefor, nor any public lands devoted thereto, shall ever be under the control of any religious sect; nor shall any money so raised or lands so devoted be divided between religious sects or denominations.' H.R.J. Res. 1, $44^{\text {th }}$ Cong., $1^{\text {st }}$ Sess., 4 CONG. REC. 205 (1875). Also available online at: www.blaineamendments.org/Intro/BAtext-US.html.

42. For a fuller overview of the political history involved with this constitutional amendment, see Mark Edward DeForrest (2003), An Overview and Evaluation of State Blaine Amendments: Origin, Scope and First Amendment Concerns, Harv. F. L. Pub. Pol. 26, 551, 556-577.

43. Scholars still dispute the extent to which anti-Catholic sentiment drove the movement to pass Blaine amendments in the states. See Laura S. Underkuffler (2003) The 'Blaine' Debate: Must States Fund Religious Schools? First Amend. L. Rev., 2 179, 195 (arguing that Blaine amendments were the products of more than a singular anti-Catholic motivation). See also Steven K. Green, 'Blaming Blaine': Understanding the Blaine Amendment and the 'NoFunding' Principle, First Amend. L. Rev. 2, 107. Yet, though anti-Catholic sentiment may not have been the single driving motivation for the passage of Blaine amendments, it played a critical role in the establishment of forces like the infamous Know-Nothing party, who vigorously supported Blaine amendments around the nation. See DeForrest, supra note 43, at 558-566. See also Phillip Hamburger (2002) Separation of Church and State (Harvard University Press); John McGreevey (2003) Catholicism and American Freedom: A History (W.W. Norton).

44. When asked whether he was, 'espousing because Article I, $₫ 3$ may have come at a time when there was bigotry, that we should weed it out of the Constitution?' counsel for the intervenors on the government's side answered, 'Not at all...[t]he provision must be...given its full force.' He then went on to argue again that the provision only bars deliberate government action undertaken to aid religion, not government action designed to assist children in failing public schools. Transcript of Oral Argument, at 13. Of course antiCatholicism could serve as a basis for striking down Section Three, under the First Amendment, if it manifested itself in such a way as to infringe on rights protected under the Free Exercise Clause.

45. 'Congress shall make no law respecting an establishment of religion, or prohibiting the free exercise thereof.' (emphasis added). US Const. amend. I. For an analysis of the salience of possible Free Exercise challenges to the Florida Blaine amendment, see Lupu and Tuttle, supra note 7 , at $957-973$.

46. 540 US 712 (2004).

47. On 30 June 2005, Ohio Governor Bob Taft signed a state budget bill that expands the Cleveland voucher program at issue in Zelman to the rest of the state. See Jim Provance, Taft Signs Budget That Overhauls Ohio Taxes: Governor Vetoes Ban on Stem Cell Aid, Toledo Blade, 1 July 2005, available online at: www.toledoblade.com/apps/pbcs.dll/article?AID =/ 20050701/NEWS24/507010557. 
Copyright of Education \& the Law is the property of Routledge and its content may not be copied or emailed to multiple sites or posted to a listserv without the copyright holder's express written permission. However, users may print, download, or email articles for individual use. 